\title{
MUNICIPAL INFRASTRUCTURE AND THE LEVEL OF FISCALISM IN LOCAL TAXES
}

\author{
Łukasz Satoła, Eng PhD'
}

Faculty of Agriculture and Economics, University of Agriculture in Krakow

\begin{abstract}
Municipalities are responsible for the condition of technical infrastructure installations, shaping the conditions of functioning of companies at the local level. The operation of municipal infrastructure generates costs that need to be financed by budgetary revenue. The aim of this paper is to identify the interdependencies between the level of municipal infrastructure provision and the level of fiscalism in property tax. The Technique for Order Preference by Similarity to Ideal Solution (TOPSIS) method was used for the synthetic assessment of the development of the municipal infrastructure. The analyses conducted confirmed the correlation between the condition of technical infrastructure and the level of fiscalism of municipalities. Municipalities with higher standard of public services related with technical infrastructure had higher property tax rates. A higher fiscalism level of municipalities is accepted if the installations allowing for a better standard of living and conducting business is provided.
\end{abstract}

Keywords: infrastructure, municipality, local taxes JEL codes: H41, H71, H72

\section{INTRODUCTION}

The introduction of territorial self-government empowered local communities giving them the right to decide in their own matters within their fields of competence (cf. De Benedictis-Kessner and Warshaw, 2016). Self-governance meant, on the one hand, the renouncement from centralised control over multiple public tasks, usually connected with defining their standard. On the other, the created territorial self-government units (mostly municipalities) gained the ability to have influence on the revenue within local tax policy over time (cf. Dupor and Guerrero, 2017).
Experience at international level shows that there are certain interdependencies between local goods or public services and the tax policy of self-governments (cf. Zodrow and Mieszkowski, 1986). According to Tiebout (1956) theoretical analysis, when choosing a place of residence, people compare the local offer of public goods with local tax level. This paper attempts to verify this relation on a local level and to assess the interdependencies between the level of fiscalism and the level of municipal infrastructure provision in based on empirical data from Poland in the period 2010-2015.

The aim of this paper is to identify the interdependencies between the level of municipal infra-

${ }^{1}$ Corresponding author: al. Mickiewicza 21,31-120 Kraków, Poland, lukasz.satola@urk.edu.pl, +4812 6624371 
structure provision of self-governments of municipalities and the level of fiscalism in property tax.

\section{THEORETICAL PREMISES OF THE IMPORTANCE OF LOCAL INFRASTRUCTURE FOR THE ECONOMIC DEVELOPMENT AND OF ITS FINANCING}

Infrastructure is crucial for socio-economic life and this is why it is the public sector's responsibility (Bond, 1999; Szewczuk and Zioło, 2008). The local technical infrastructure is a part of municipal property and is controlled by territorial self-government units, mostly municipalities.

The research of the role of infrastructure in economic growth is connected with the so-called bigpush concept according to which exceeding a certain developmental threshold allowing for self-stimulation and the sustainability of growth and development processes is particularly problematic for deprived areas (Rosenstein-Rodan, 1961; Ratajczak, 2000). In the theory of economy, there are at least two different views on the relation between infrastructure and economic development. According to the first one, represented by Ragnar Nurkse, the creation of infrastructure elements is a condition for, therefore should precede, economic development processes (Nurkse, Haberler and Stern, 1962). Hirschman (1964) did not agree with this opinion and believed that the economy goes through particular development phases with temporary insufficiency of infrastructure. It means that infrastructure objects are created in the consequence of the economic development of regions.

The functioning of the infrastructure sector is often considered an example of a natural monopoly. High market entry barriers related with a very high cost of creating infrastructure objects (sometimes referred to as sunk costs, as they cannot be recouped) are characteristic for this market structure. On the other hand, when the infrastructure already exists, the costs of providing another unit of goods are low, which leads to low marginal costs.

A natural monopoly is a sign of market failure concerning the infrastructure sector and takes the following forms (cf. Szablewski, 1991):
- Production scale increase takes place with a downward average costs curve. It means that the lowest cost of total demand satisfaction is possible only when there is only one supplier on the market.

- External effects are related with infrastructure development. External benefits appear when the functioning of one entity has positive effects for other entities without due compensation from them (cf. Barro, 1990). Under the conditions of a market economy, due to the lack of possibilities to internalise these benefits, there is a risk of lower than socially expected level of supply of infrastructure services and goods.

- Spatial and physiographic conditions as well as material situation of the residents may significantly diversify the costs of support of infrastructure services recipients and their price. However, due to the fact that they mostly satisfy basic needs, more egalitarian ways of their distribution are needed.

\section{MATERIALS AND METHODS}

The primary source of data included data about property tax rates obtained from resolutions of municipal councils in Poland. Another source of data about the level of municipal infrastructure development were the indexes of the percentage of persons serviced by waterworks and sewerage networks, and gas networks obtained from the CSO Local Data Bank. Due to the large scope of analysed data, the spatial scope was limited to the Małopolskie province municipalities (182) and the temporal scope to six years (2010 -2015). The property tax was chosen from local taxes due to its greatest significance in own revenue and the widest range of application of fiscal sovereignty instruments (Przygodzka, 2014).

Due to the complexity of the analysed phenomena (they are described by many sub-indices), the TOPIS (Technique for Order Preference by Similarity to Ideal Solution) method was used for synthetic assessment. This method is a multi-criteria method of decision support and a benchmark method of synthetic measure creation (Hwang and Yoon, 1981).

The value of the synthetic measure was determined in the following order: 
1. Normalisation of simple characteristics value - unification of characteristics by transforming dampers into boosters using zero unitarisation through the following formulas:

$$
\begin{aligned}
& z_{i j}=\frac{x_{i j}-\min _{i} x_{i j}}{\max _{i} x_{i j}-\min _{i} x_{i j}}, \text { when } X_{j} \in S \\
& z_{i j}=\frac{\max _{i} x_{i j}-x_{i j}}{\max _{i} x_{i j}-\min _{i} x_{i j}}, \text { when } X_{j} \in D
\end{aligned}
$$

$S$ - stimulants,

$D$ - destimulants.

2. Determining the coordinates of the pattern and anti-pattern of development:

$A^{+}=\left(\max _{i}\left(z_{i 1}\right), \max _{i}\left(z_{i 2}\right), \ldots, \max _{i}\left(z_{i j}\right)\right)=\left(z_{1}^{+}, z_{2}^{+}, \ldots, z_{j}^{+}\right)$

$A^{-}=\left(\min _{i}\left(z_{i 1}\right), \min _{i}\left(z_{i 2}\right), \ldots, \min _{i}\left(z_{i j}\right)\right)=\left(z_{1}^{-}, z_{2}^{-}, \ldots, z_{j}^{-}\right)$

3. Developing Euclidean distances of particular objects from the pattern and anti-pattern of development:

$$
\begin{aligned}
& d_{i}^{+}=\sqrt{\sum_{j=1}^{m}\left(z_{i j}-z_{j}^{+}\right)^{2}} \\
& d_{i}^{-}=\sqrt{\sum_{j=1}^{m}\left(z_{i j}-z_{j}^{-}\right)^{2}}
\end{aligned}
$$

4. Determining synthetic measurement values for particular objects based on the following formula:

$$
q_{i}=\frac{d_{i}^{-}}{d_{i}^{-}+d_{i}^{+}}, \quad i=1,2, \ldots, n
$$

These calculations allowed for a ranking of municipalities based on the level of provision of technical infrastructure to be created. This criterion was later used for objects grouping. The following indicators were used to measure the infrastructural equipment of municipalities: share of inhabitants served by water supply network, share of people using the sewage network and the share of people served by the gas network. The synthetic results of the analyses are presented in tables.

\section{RESULTS AND DISCUSSION}

The high costs of municipal infrastructure creation requires searching for financing sources (Chan et al., 2009; Wagenvoort, Nicola and Kappeler, 2011). Territorial self-government units may use both internal and external investment financing. The spectrum of external sources is wide and includes returnable and non-returnable financing of self-government investment tasks. However, they are not the subject of this paper and will not be analysed in detail here. Internal sources provide the highest decision-making autonomy, but often, they do not guarantee enough funds to cover all investment projects costs. Among the internal sources, own revenue that directly determines the possibilities of development is considered the most important. Local tax and fees are also important, as they are not only a source of financing of the budget, but also allow affecting the behaviours of entities they apply to. It means that decisions within the local tax policy can affect the amount of budget revenues and the behaviour of taxpayers subject to local taxes.

The fiscal sovereignty of municipalities is executed primarily through shaping tax rates (cf. Przygodz$\mathrm{ka}, 2014$ ) within the limits laid down in the relevant legislative acts.

In the studied period, the municipalities increased property tax rates both with regards to residential and business buildings, whereby these changes were not big (Table 1). The rates for residential buildings grew slightly faster (1.19) than these for persons conducting business activity (1.13). It is worth noting that on average, the rates for residential buildings were lower ( $73 \%$ of maximal rates) than for business-related buildings ( $76 \%$ of maximal rates). In residential buildings taxation, spatial diversification is higher than in commercial buildings, as proved by coefficients of variation.

The synthetic assessment of the level of development of municipal infrastructure using the TOPIS method allowed for arranging groups of municipalities and distinguishing groups with similar levels of 
Proceedings of the 2018 International Scientific Conference 'Economic Sciences for Agribusiness and Rural Economy' No 1, Warsaw, 7-8 June 2018, pp. 370-375

Table 1. Comparison of selected statistical measures of property tax rates in Małopolskie province municipalities $\left(\mathrm{PLN} / \mathrm{m}^{2}\right)$

\begin{tabular}{|l|c|c|c|c|c|c|c|c|c|c|c|c|}
\hline \multirow{2}{*}{ Specification } & \multicolumn{2}{|c|}{2010} & \multicolumn{2}{c|}{2011} & \multicolumn{2}{c|}{2012} & \multicolumn{2}{|c|}{2013} & \multicolumn{2}{|c|}{2014} & \multicolumn{2}{c|}{2015} \\
\cline { 2 - 14 } & $\mathrm{A}$ & $\mathrm{B}$ & $\mathrm{A}$ & $\mathrm{B}$ & $\mathrm{A}$ & $\mathrm{B}$ & $\mathrm{A}$ & $\mathrm{B}$ & $\mathrm{A}$ & $\mathrm{B}$ & $\mathrm{A}$ & $\mathrm{B}$ \\
\hline Mean & 0.46 & 15.60 & 0.48 & 15.91 & 0.51 & 16.80 & 0.54 & 17.38 & 0.55 & 17.60 & 0.55 & 17.64 \\
\hline Median & 0.49 & 16.00 & 0.50 & 16.00 & 0.54 & 17.00 & 0.55 & 17.57 & 0.56 & 17.88 & 0.57 & 17.91 \\
\hline $\begin{array}{l}\text { Standard } \\
\text { deviation }\end{array}$ & 0.13 & 2.58 & 0.13 & 2.59 & 0.14 & 2.67 & 0.13 & 2.70 & 0.14 & 2.74 & 0.14 & 2.74 \\
\hline $\begin{array}{l}\text { Coefficient } \\
\text { of variation }\end{array}$ & 0.27 & 0.17 & 0.27 & 0.16 & 0.26 & 0.16 & 0.25 & 0.16 & 0.25 & 0.16 & 0.25 & 0.16 \\
\hline
\end{tabular}

A - residential buildings; B - buildings related with economic activity

Source: own research.

availability of infrastructure installations. Based on the synthetic measure, 4 groups of entities were distinguished:

- I group - with the lowest development level $\left(q_{i}<0.33266\right)$,

- II group - with low development level $\left(0.33266<q_{i}<0.45294\right)$,

- III group - with medium development level $\left(0.45294<q_{i}<0.60495\right)$,

- IV group - with the highest development level $\left(q_{i}>0.60495\right)$.

The classification of municipalities allowed for indicating areas with the best and the worst standard of public services. The group of entities with the highest level of technical infrastructure development includes mostly large cities and local development centres.
Rural municipalities in this group are mostly located next to the largest cities of the region or their dominant function is tourism. Peripherally located municipalities (mostly from southern and eastern parts of the region) dominated the group of entities with the lowest development level. These entities have a low level of entrepreneurship and a weak non-agricultural labour market and are exposed to migration (cf. Wojewódzka-Wiewiórska, and Dudek, 2016).

To assess the relations between the fiscalism level of municipalities in terms of property tax and the level of development of municipal infrastructure, the tax rates in particular groups were analysed. The groups were distinguished based on the value of synthetic measure obtained using the TOPSIS method (Table 2).

Table 2. Comparison of property tax rates as percentage of maximum rate in Małopolskie province based on the level of development of municipal infrastructure (\%)

\begin{tabular}{|l|c|c|c|c|c|c|c|c|c|c|c|c|}
\hline \multirow{2}{*}{ Specification } & \multicolumn{2}{|c|}{2010} & \multicolumn{2}{|c|}{2011} & \multicolumn{2}{c|}{2012} & \multicolumn{2}{|c|}{2013} & \multicolumn{2}{|c|}{2014} & \multicolumn{2}{c|}{2015} \\
\cline { 2 - 13 } & $\mathrm{A}$ & $\mathrm{B}$ & $\mathrm{A}$ & $\mathrm{B}$ & $\mathrm{A}$ & $\mathrm{B}$ & $\mathrm{A}$ & $\mathrm{B}$ & $\mathrm{A}$ & $\mathrm{B}$ & $\mathrm{A}$ & $\mathrm{B}$ \\
\hline I group & 66.5 & 70.8 & 66.9 & 70.4 & 68.4 & 70.7 & 69.7 & 70.9 & 69.8 & 71.0 & 68.9 & 70.7 \\
\hline II group & 67.6 & 72.8 & 67.8 & 72.4 & 69.5 & 73.8 & 71.4 & 73.2 & 71.8 & 73.7 & 70.9 & 73.4 \\
\hline III group & 72.6 & 76.3 & 72.5 & 76.1 & 74.6 & 77.7 & 74.6 & 77.0 & 75.4 & 77.2 & 74.4 & 76.9 \\
\hline IV group & 79.4 & 84.5 & 78.1 & 83.5 & 80.3 & 84.3 & 80.2 & 83.6 & 80.6 & 83.8 & 79.5 & 83.4 \\
\hline
\end{tabular}

A - residential buildings; B - buildings related with economic activity.

Source: own research. 
The analysis confirmed the relation between the level of development of technical infrastructure and the level of fiscalism of municipalities in terms of property tax. The average taxation level was the lowest in municipalities with the lowest level of availability of public services. The higher the level of equipment with municipal infrastructure installations, the higher the level of fiscalism. The units with the highest level of infrastructure equipment had the highest property tax rates (expressed as percentage of maximum rates - Table 2). Therefore, residents incur higher costs in exchange for a higher standard of public services provided by the local self-government.

Each year, the level of fiscalism with regards to residential and business-related buildings increased along with the improvement of infrastructure availability. It is worth noting that the greatest differences are observed between the 3rd and 4th group, which may lead to a conclusion that the municipalities offering the best municipal infrastructure have significantly higher taxes. Although the average level of fiscalism is higher in the case of buildings used for business purposes than in case of residential buildings, it is worth noticing that this difference is decreasing. This is due to the faster growth of residential building tax rates.

\section{CONCLUSION}

The level of development of municipal infrastructure determines the conditions of life of the residents and is an important factor of the location of companies. In shaping their public services offer in terms of technical infrastructure, municipalities affect their competitiveness towards neighbouring entities.

The construction and maintenance of infrastructure requires expenditures from local budgets. The question of whether the level of development of municipal infrastructure with the scope of fiscalism with regards to local taxes arises. The conducted research confirmed the existence of such a relation. The higher the municipalities' fiscalism in terms of property tax, the better the quality and availability of the municipal infrastructure.

Municipalities offering a higher public services standard to their residents and entrepreneurs compensate the increase of infrastructure operation costs with higher taxes. Attempting to maintain a vast offer of public services while keeping the fiscalism level low would increase the debt of territorial self-government.

Territorial self-government units aiming toward improving the conditions of technical infrastructure should provide for an increase of the revenue from local taxes allowing them to cover growing maintenance costs in their long-term financial plans. Achieving residents' acceptance of growing tax rates is possible if the quality of life and conducting business improve.

\section{REFERENCES}

1. Barro, R.J. (1990). Government spending in a simple model of endogeneous growth. Journal of political economy, 98 (5), Part 2, pp. 103-125.

2. Benedictis-Kessner, de J., Warshaw, C. (2016). Mayoral partisanship and municipal fiscal policy. The Journal of Politics, 78 (4), pp. 1124-1138.

3. Bond, P. (1999). Basic infrastructure for socio-economic development, environmental protection and geographical desegregation: South Africa's unmet challenge. Geoforum, 30 (1), pp. 43-59.

4. Chan, C., Forwood, D., Roper, H., Sayers, C. (2009). Public infrastructure financing: an international perspective. Productivity Commission Staff Working Paper, Australian Government

5. Dupor, B., Guerrero, R. (2017). Local and aggregate fiscal policy multipliers. Journal of Monetary Economics, 92, pp. 16-30.

6. Hirschman, A.O. (1964). Stratégie du développement économique [Economic Development Strategy]. Ouvrières

7. Hwang, C.L., Yoon, K. (1981). Multiple Attributes Decision Making Methods and Applications. Springer, Berlin.

8. Nurkse, R., Haberler, G., Stern, R.M. (1962). Equilibrium and growth in the world economy. Harvard University Press, Cambridge, MA.

9. Przygodzka, R. (2014). Władztwo podatkowe a stabilność finansowa gmin (The Tax Control and the Financial Stability of Communes]. Nierówności Społeczne a Wzrost Gospodarczy, 40, pp. 334-343.

10. Ratajczak, M. (2000). Infrastruktura a wzrost i rozwój gospodarczy [The infrastructure and economic growth and development]. Ruch Prawniczy. Ekonomiczny i Socjologiczny, 4, pp. 83-102. 
11. Rosenstein-Rodan, P.N. (1961). Notes on the theory of the 'big push'. In: Economic Development for Latin America. Palgrave Macmillan, London, pp. 57-81.

12. Szablewski, A. (1991). Teoretyczne przesłanki deregulacji gałęzi infrastrukturalnych [Theoretical premises for deregulation of infrastructural branches]. In: Studia i Materiały PAN, 40, p. 48

13. Szewczuk, A., Zioło, M. (2008). Zarys ekonomiki sektora publicznego [The outline of public sector economics]. Wydawnictwo Naukowe Uniwersytetu Szczecińskiego, Szczecin.

14. Tiebout, Ch. (1956), A pure theory of local expenditure. Journal of Political Economy, 64, pp. 416-424.
15. Wagenvoort, R., De Nicola, C., Kappeler, A. (2010). Infrastructure finance in Europe: Composition, evolution and crisis impact. EIB Papers, 15 (1), pp. 16-39.

16. Wojewódzka-Wiewiórska, A., Dudek, H. (2016). Dynamics of Rural Areas Development in Poland; Convergence Analysis. Research for Rural Development. Vol. 2. In: Proceedings of 22nd Annual International Scientific Conference, Jelgava, pp. 99-105

17. Zodrow, G.R., Mieszkowski, P. (1986). Pigou, Tiebout, property taxation, and the under provision of local public goods. Journal of urban economics, 19 (3), pp. 356-370. 